\title{
LH secretion and response to GnRH during seasonal anoestrus of the Père David's deer hind (Elaphurus davidianus)
}

\author{
J. D. Curlewis $†$, B. J. McLeod* $\ddagger$ and A. S. I. Loudon \\ M.R.C./A.F.R.C. Comparative Physiology Research Group, The Institute of Zoology, The \\ Zoological Society of London, Regent's Park, London NWI 4RY,UK; and *AFRC Institute for \\ Grassland and Animal Production, Hurley, Maidenhead, Berks SL6 SLR, UK
}

\begin{abstract}
Summary. The pattern of LH secretion and response to exogenous GnRH was determined on 5 occasions during seasonal anoestrus of the Père David's deer hind. LH pulse frequency was low $(3.3 \pm 0.6$ pulses $/ 18 \mathrm{~h})$ in early anoestrus (February), increased significantly in mid-anoestrus (April; $8.4 \pm 1.4$ pulses/18 h) and thereafter declined slightly in late anoestrus (June; $6 \cdot 3 \pm 0 \cdot 25$ pulses $/ 18 \mathrm{~h}$ ). Mean LH concentrations also showed significant changes during anoestrus with higher levels in midanoestrus (April; $0.85 \pm 0.12 \mathrm{ng} / \mathrm{ml})$ when compared with other times $(0.53 \pm 0.05$, $0.60 \pm 0 \cdot 10,0.68 \pm 0.06$ and $0.71 \pm 0.05 \mathrm{ng} / \mathrm{ml}$ for February, March, May and June, respectively). LH pulse amplitude showed no significant changes during the study. The $\mathrm{LH}$ response to intravenous injections of $2 \mu \mathrm{g} \mathrm{GnRH}$ was lowest in early anoestrus (February), increased significantly in mid-anoestrus (April) and remained high through late anoestrus. The response during the luteal phase was similar to that seen during late anoestrus. These results indicate that seasonal anoestrus in the Père David's deer hind is not a uniform state but is characterized by an early period of 'deep' anoestrus.
\end{abstract}

Keywords: LH; deer; GnRH; seasonal anoestrus; breeding season

\section{Introduction}

Luteinizing hormone (LH) is secreted by the pituitary in discrete pulses (Katongole et al., 1971) which are a direct consequence of episodic release of gonadotrophin-releasing hormone ( $\mathrm{GnRH})$ from the hypothalamus (Clarke \& Cummins, 1982). During seasonal anoestrus in the ewe, LH pulse frequency is reduced (Scaramuzzi \& Baird, 1977; Yuthasastrakosol et al., 1977), presumably due to a reduction in $\mathrm{GnRH}$ pulse frequency. A change in pituitary responsiveness to GnRH during anoestrus has not been reported in sheep. In the absence of adequate gonadotrophic stimulation, ovarian follicles do not undergo the final stages of development which are required for ovulation to occur (McNatty et al., 1984). Replacement with either GnRH or LH during seasonal anoestrus in the ewe results in preovulatory follicle development and ovulation (McNatty et al., 1981; McLeod et al., 1982; McNeilly et al., 1982).

LH pulse frequency is low and does not change during seasonal anoestrus in the ewe. Further, sensitivity to oestradiol negative feedback on LH secretion undergoes relatively abrupt changes, decreasing and increasing acutely at the onset and termination of the breeding season respectively (Legan et al., 1977). Taken together, these data suggest that seasonal anoestrus in the ewe is a

\footnotetext{
†Present address: Department of Physiology and Pharmacology, University of Queensland, St Lucia, Queensland 4072, Australia.

${ }_{\ddagger}^{\ddagger}$ Present address: Invermay Agricultural Centre, Private Bag, Mosgiel, New Zealand.
} 
uniform physiological state in which there is high sensitivity to oestradiol negative feedback resulting in low LH pulse frequency (Karsch et al., 1985). Therefore it would be predicted that in the period leading to the onset of the breeding season there would be an increase in LH pulse frequency which would account for increased follicle development and the subsequent events which lead to ovulation. This has proved difficult to demonstrate (Walton et al., 1980; Poulton et al., 1987) except when ewes have been sampled very close to the onset of the breeding season (I'Anson \& Legan, 1988).

Genetic selection and the associated domestication of sheep has resulted in breeds with various degrees of seasonality. For example non-pregnant Welsh mountain, Suffolk and Dorset horn ewes show repeated oestrous cycles for periods of 182, 191 and 265 days per year (Legan \& Karsch, 1979; Webster \& Haresign, 1983). In contrast wild ungulates such as the red and Père David's deer hinds show a more restricted breeding season with reproductive cycles in non-pregnant animals occurring for 160 days per year (Curlewis et al., 1988a; Loudon et al., 1989). The present study was undertaken to determine whether the model for LH secretion during anoestrus in the ewe can also be applied to a more seasonal species such as the Père David's deer (Elaphurus davidianus). We wished to determine (a) whether there is a change in the pattern of LH secretion from early to late anoestrus and (b) whether there is a change in the response to administered GnRH over the same period. The response to GnRH was compared with that recorded during the luteal phase of a reproductive cycle.

\title{
Materials and Methods
}

\begin{abstract}
Animals. Five tame adult Père David's deer hinds (live weight $173 \pm 5 \cdot 2 \mathrm{~kg}$, s.e.m.) were used in the study. Between experiments they were maintained on pasture at Whipsnade Park, Bedfordshire (latitude $50^{\circ} 30^{\prime} \mathrm{N}$ ). At least 2 days before each period of intensive sampling was to begin, hinds were moved indoors and housed individually in pens $(4 \times 3 \mathrm{~m})$ and on deep litter and under natural photoperiod and environmental temperature. Dim red artificial light was used to assist collection of blood samples during periods of darkness.
\end{abstract}

Collection of blood samples and experimental design. The day before each of 5 periods of intensive blood sampling, hinds were sedated with xylazine ( $40 \mathrm{mg}$, s.c.; Bayer Pharmaceuticals, Leverkusen, West Germany) and a jugular cannula was inserted. The sedative effects of xylazine lasted $2-4 \mathrm{~h}$ with hinds apparently normal on the following day. On subsequent days it was possible to collect blood from the jugular cannula without need for physical restraint of the deer.

Profiles of plasma LH concentrations were determined on 5 occasions at 4- or 5-week intervals during seasonal anoestrus (11 February, 17 March, 23 April, 27 May and 24 June). On each of these occasions, blood samples (4 ml) were collected ai is-nin intervals for $18 \mathrm{~h}$. One hind from which the cannula was lost was omitted from blood sampling on 24 June.

On the day after each of the LH profile bleeds, the animals were subjected to a GnRH challenge. Each hind was given 4 intravenous injections (via the jugular vein cannula) of $2.0 \mu \mathrm{g} \mathrm{GnRH}$ (Lutal; Fabwerke Hoechst A.G, Frankfurt, West Germany) in $2.0 \mathrm{ml}$ sterile saline $(0.9 \% \mathrm{NaCl})$, administered at 2 - $\mathrm{h}$ intervals. Preliminary studies in anoestrous hinds showed that this was the lowest dose of GnRH which consistently increased plasma LH in all hinds. Blood samples were taken at 15 -min intervals for $7.5 \mathrm{~h}$. The first $\mathrm{GnRH}$ injection was given immediately after the second blood sample. One hind was omitted from the GnRH challenges on 26 May (B74) and 24 June (Y12) due to lost cannulae.

The response to repeated injections of $2 \mu \mathrm{g} \mathrm{GnRH}$ was also determined on Day 8 of the luteal phase after oestrus had been synchronized with progesterone-impregnated silicone-elastomer implants (Sil-Estrus, Ceva Ltd, Sydney, Australia) and injection of prostaglandin (Estrumate; Coopers Animal Health, Crewe, Cheshire, UK) as previously described (Loudon et al., 1990).

In all periods of intensive blood sampling, blood was collected into heparinized tubes, centrifuged immediately and the plasma stored at $-20^{\circ} \mathrm{C}$ until assayed.

Duration of seasonal anoestrus. The duration of seasonal anoestrus was determined by measuring progesterone concentration in plasma samples which were collected twice weekly by jugular venepuncture between 1 December 1986 and 18 August 1987. The onset of seasonal anoestrus was defined as the date when plasma progesterone concentrations fell below $0.3 \mathrm{ng} / \mathrm{ml}$ following the last luteal phase of the breeding season. The onset of the breeding season was defined as the date of the first increase in progesterone concentrations above $1 \mathrm{ng} / \mathrm{ml}$ for more than two consecutive samples. 
Radioimmunoassays. Plasma LH concentrations were measured using an ovine LH radioimmunoassay (McLeod et al., 1982) which has been validated for deer LH (Loudon et al., 1990). The limit of sensitivity of the assay was $0.2 \mathrm{ng} / \mathrm{ml}$ and the intra- and inter-assay coefficients of variation were 8.6 and $9.8 \%$ respectively. Progesterone concentrations were measured as previously described (Curlewis et al., 1988a). The limit of sensitivity of the assay was $0.08 \mathrm{ng} / \mathrm{ml}$ and the intra- and inter-assay coefficients of variation were 3.8 and $10.5 \%$ respectively.

Analysis of data. An LH episode was defined by the criteria of Loudon et al. (1990); i.e. (i) an increase in plasma LH concentrations of at least 4 times the intra-assay coefficient of variation, (ii) no more than one sample point between the preceding trough and peak value, and (iii) there was at least 1 sample point between the peak and succeeding trough. LH pulse frequency (pulses/18 h) and mean $\mathrm{LH}$ were determined. Pulse amplitude was calculated by subtracting the concentration at the preceding trough from the peak value.

The response to GnRH was calculated as the difference in plasma LH concentrations between the sample taken immediately before injection and the peak response occurring within $30 \mathrm{~min}$ of injection. In $81 \%$ of cases, the maximum LH concentration was recorded in the sample taken $15 \mathrm{~min}$ after injection of $\mathrm{GnRH}$.

Statistical analyses were performed using within subject, repeated measure analysis of variance. When significant treatment effects were identified, group means were compared by least significant difference. Data from the GnRH challenge were not normally distributed and were therefore log transformed before analysis. Analyses of pulsatile $\mathrm{LH}$ characteristics during anoestrus were on non-transformed data.

\section{Results}

\section{Duration of seasonal anoestrus}

Mean date for the onset of anoestrus was 2 January ( \pm 4.7 days; s.e.m.). Plasma progesterone concentrations then remained low $(<0.3 \mathrm{ng} / \mathrm{ml})$ in all animals until the period between 21 and 31 July when transient increases in progesterone concentration to $0.3-1.0 \mathrm{ng} / \mathrm{ml}$ occurred in all hinds. The breeding season began on 4 August in all hinds.

\section{Plasma LH profiles during anoestrus}

Mean LH concentrations, LH pulse frequency and pulse amplitude recorded in the 18-h sampling periods throughout anoestrus are summarized in Fig. 1. There was a significant $(P<0.01$, ANOVA $)$ change in pulse frequency over the period of seasonal anoestrus. In early anoestrus mean $\mathrm{LH}$ pulse frequency was low $(3.3 \pm 0.6$ and $3.7 \pm 0.62$ pulses/18 $\mathrm{h}$ in February and March respectively), increased significantly $(P<0.01)$ in mid-anoestrus (April, $8.4 \pm 1.40$ pulses/ $18 \mathrm{~h})$, and remained high in late anoestrus $(7.0 \pm 1.41$ and $6.3 \pm 0.25$ pulses $/ 18 \mathrm{~h}$ in May and June respectively).

Mean LH concentrations were significantly greater $(P<0.05$; see Fig. 1$)$ in mid-anoestrus $(0.85 \pm 0.12 \mathrm{ng} / \mathrm{ml}$, April) than in early $(0.53 \pm 0.05$ and $0.60 \pm 0.10 \mathrm{ng} / \mathrm{ml}$ in February and March respectively) and late anoestrus $(0.68 \pm 0.06$ and $0.71 \pm 0.05 \mathrm{ng} / \mathrm{ml}$ in May and June respectively).

Although changes in $\mathrm{LH}$ pulse amplitude followed a trend similar to those of pulse frequency and mean LH (i.e. highest in mid-anoestrus), these were not significant $(P>0 \cdot 1)$.

\section{Response to GnRH during anoestrus and the breeding season}

Mean LH concentrations during the GnRH challenges and mean $\mathrm{LH}$ response to GnRH during anoestrus and the luteal phase of the oestrous cycle are summarized in Figs 2 and 3 respectively. The mean $\mathrm{LH}$ response changed significantly $(P<0.01)$ during the anoestrous period. Response was lowest in early anoestrus (February, $1.2 \pm 0.12 \mathrm{ng} / \mathrm{ml})$, increased significantly $(P<0.01)$ in mid-anoestrus (April, $2.3 \pm 0.60 \mathrm{ng} / \mathrm{ml}$ ) and remained increased until late anoestrus (June, $2.3 \pm 0.49 \mathrm{ng} / \mathrm{ml})$. The response to $\mathrm{GnRH}$ during the luteal phase $(3.0 \pm 0.8 \mathrm{ng} / \mathrm{ml})$ was similar to that seen during mid- to late anoestrus but was significantly $(P<0.01)$ greater than that recorded in early anoestrus (February and March). When all animals and all stages of the season were combined, there was also a significant effect $(P<0.01)$ of the order of injection of GnRH. The 

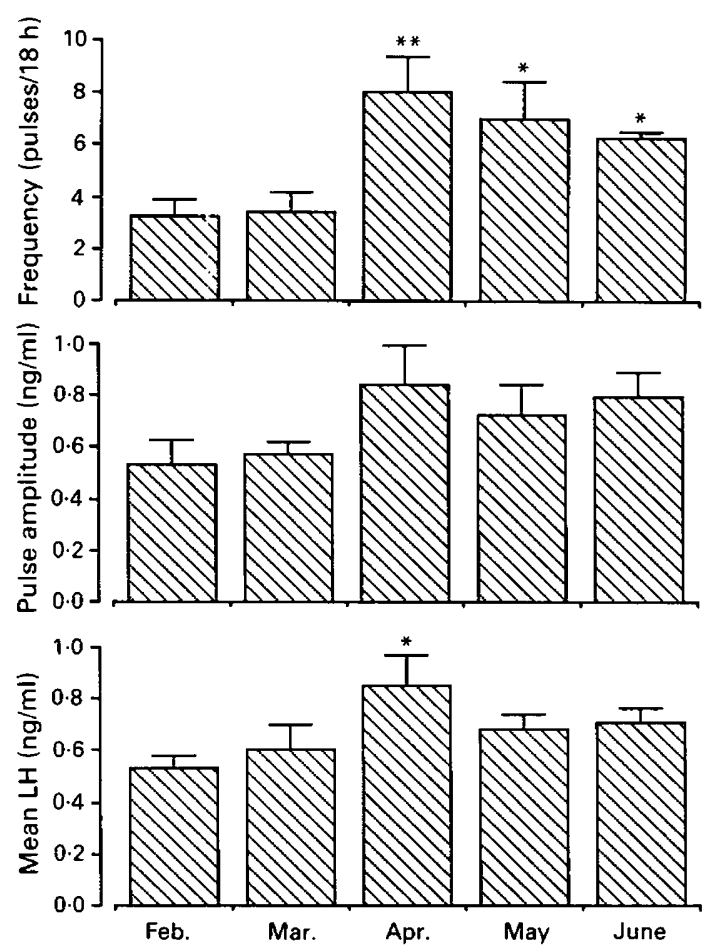

Fig. 1. Summary of LH pulse characteristics during seasonal anoestrus of the Père David's deer hind $(N=5) .{ }^{* *} P<0.01,{ }^{*} P<0.05$ compared with February values.

response to the third injection was significantly greater $(P<0.01)$ than the response to the first and fourth injections. There was no interaction between time of year and response to repeated injection $(P>0 \cdot 1)$.

\section{Discussion}

This study of endogenous and GnRH-induced patterns of LH secretion in the Père David's deer hind demonstrates that changes in LH release occur over the period of seasonal anoestrus. In untreated hinds, mean $\mathrm{LH}$ concentrations and $\mathrm{LH}$ pulse frequencies were significantly higher in mid-anoestrus than in early anoestrus. In addition, the magnitude of the $\mathrm{LH}$ response to administration of $\mathrm{GnRH}$ was significantly greater in mid- and late anoestrus, than in early anoestrus. Such variation in gonadotrophin secretion during the period of acyclicity has not previously been reported for a seasonally breeding species. The lower LH pulse frequency and LH response to GnRH in early anoestrus suggests that suppression of the reproductive axis is greatest at this time, supporting the novel concept that these animals are more 'deeply' anoestrus immediately after the end of the breeding season.

It is well established that, in the ewe, mean LH concentrations are higher during the breeding season than during seasonal anoestrus. In addition, studies involving ovariectomized, oestradioltreated ewes have shown that mean LH concentrations fall abruptly at the onset of seasonal anoestrus and remain at a low level throughout the anoestrous period (Legan \& Karsch, 1979; Webster \& Haresign, 1983). There is little information available regarding episodic patterns of LH secretion at different times during the anoestrous period in sheep. Studies of ovariectomized, 

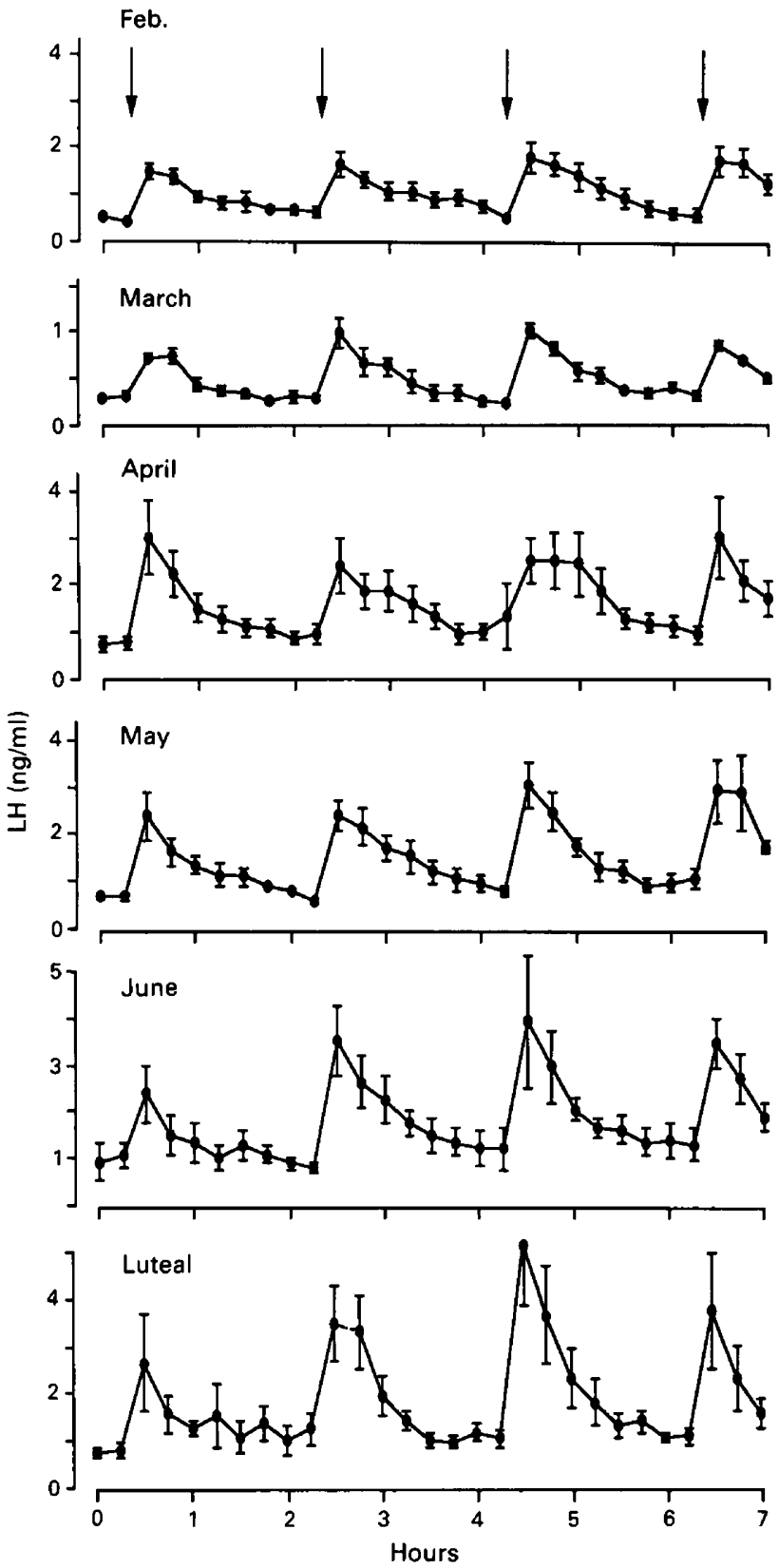

Fig. 2. Mean \pm s.e.m. plasma LH concentrations in Père David's deer hinds treated every $2 \mathrm{~h}$ with $2.0 \mu \mathrm{g} \mathrm{GnRH}$ (arrow) on 5 occasions during seasonal anoestrus and during the luteal phase.

oestrogen-implanted ewes indicated no changes in the frequency of LH episodes until as little as 10-20 days (Walton et al., 1980) before the first ovulation of the breeding season, while in the ovary-intact ewe an increase in LH pulse frequency was only seen 7-28 days (I'Anson \& Legan, 1988 ) before the first ovulation of the breeding season. The results from the present study do not preclude the occurrence of a further increase in LH pulse frequency in the hind immediately before 


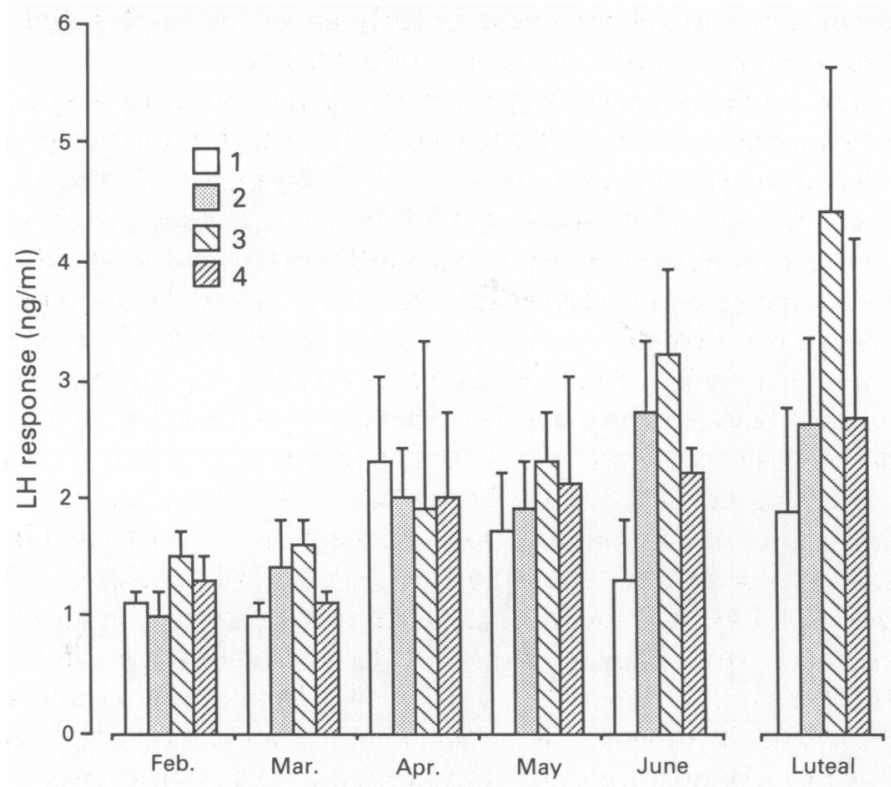

Fig. 3. $\mathrm{LH}$ response to injection of $2 \mu \mathrm{g} \mathrm{GnRH}$ on 5 occasions during seasonal anoestrus and at Day 8 of the luteal phase of the Père David's deer hind $(N=5)$. On each occasion 4 injections were given at $2-\mathrm{h}$ intervals.

the onset of the breeding season, as the last profile of $\mathrm{LH}$ secretion undertaken ( $24 \mathrm{June}$ ) was almost 6 weeks before the first full-length luteal phase of the breeding season.

In the ewe there is an inverse relationship between LH pulse amplitude and frequency which is evident both during anoestrus and the breeding season (Clarke \& Cummins, 1985). This relationship was not found in the present study of the hind. On the contrary pulse amplitude showed an increase, albeit non-significant, when pulse frequency increased. Similarly, it has been reported that the large-amplitude pulses that occur every $8-12 \mathrm{~h}$ during the luteal phase in the ewe were not evident in the hind (Loudon et al., 1990).

The pulse frequency recorded in mid-anoestrus (April) approached that seen during the follicular phase of the oestrous cycle ( 0.59 pulses/h or 10.6 pulses $/ 18$ h; Loudon et al., 1990). Presumably in mid-anoestrus, this pulse frequency is not sufficient to promote fully preovulatory follicle development. Alternatively, FSH concentrations may have been inadequate. A further possibility is that plasma prolactin concentrations may be important in the control of follicle development or ovulation in this species. Although prolactin does not appear to be important in controlling seasonal reproduction in the ewe (Niswender, 1974; Land et al., 1980; Rodway et al., 1983), in the red deer hind, suppression of prolactin with bromocriptine is associated with a delay in the onset of seasonal anoestrus (Curlewis et al., 1988b) and prolactin concentrations are increased during anoestrus in the Père David's deer hind (Loudon et al., 1989). Further studies are required to determine whether the seasonal changes in prolactin are causally linked with seasonal reproduction in this species.

We are not aware of published information on follicular dynamics or oestradiol secretion during seasonal anoestrus in the hind. It is therefore not possible to relate the patterns of LH secretion reported here to functional changes in the ovary. However, in experiments in which pulsed or continuous administration of GnRH was used to induce ovulation during anoestrus, clear differences were observed between animals treated in early (February and March) and late (May and June) anoestrus (McLeod et al., 1991). Significantly fewer hinds ovulated in response to this treatment in early than late anoestrus ( $23 \%$ compared with $75 \%$, respectively). It is possible 
that the poorer response to GnRH treatment in early anoestrus reflects differences in follicle populations or responsiveness to $\mathrm{GnRH}$ at the time of treatment.

There have been few studies of gonadotrophin secretion in response to exogenous GnRH given at different stages of seasonal anoestrus in the female. In the ovariectomized ewe, the LH response to GnRH is diminished during anoestrus (Land et al., 1979; Bittman et al., 1985) while in the intact ewe the response to a supra-physiological dose of $\mathrm{GnRH}$ does not change across anoestrus (Reeves et al., 1974). In the present study, the $\mathrm{LH}$ response to $\mathrm{GnRH}$ in the hind was poor in early anoestrus and showed a significant increase from early to late anoestrus. Indeed the response in late anoestrus (June) was not significantly different from that seen in the luteal phase of the oestrous cycle. Furthermore we have again shown in a separate study that there is a significant increase in pituitary responsiveness to GnRH between early and late anoestrus (McLeod et al., 1991). Although an increase in pituitary responsiveness from early to late anoestrus may be due to the priming effect of an increasing frequency of endogenous GnRH pulses, this cannot account for the response recorded in the luteal phase. At this time LH pulse frequency is similar to that in early anoestrus and yet the pituitary response to GnRH is significantly greater. Bittman et al. (1985) have shown that a physiological dose of GnRH releases $\mathrm{LH}$ in the anoestrous ewe, concluding that low $\mathrm{LH}$ pulse frequency during anoestrus is unlikely to be due to the failure of the pituitary to respond to endogenous GnRH. However, in view of the large change in pituitary responsiveness to GnRH during anoestrus in the hind, it remains possible that a failure of the pituitary to respond to $\mathrm{GnRH}$ may contribute to the low LH pulse frequency characteristic of early anoestrus.

We thank Alison Beasey and Barrie Eves for care of the animals and assistance with collection of samples at Whipsnade; Dr B. Brinklow for assistance during the later stages of the study; Hoechst for the gift of GnRH; and the NIDDK and National Hormone and Pituitary Program for the gift of ovine pituitary hormones. This study was funded in part by an AFRC project grant.

\section{References}

Bittman, E.L., Kaynard, A.H., Olster, D.H., Robinson, J.E., Yelion, S.M. \& Karsch, F.J. (1985) Pineal melatonin mediates photoperiodic control of pulsatile luteinizing hormone secretion in the ewe. Neuroendocrinology 40, 409-418.

Clarke, I.J. \& Cummins, J.T. (1982) The temporal relationship between gonadotropin releasing hormone (GnRH) and luteinizing hormone (LH) secretion in ovariectomized ewes. Endocrinology 111, 1737-1739.

Clarke, I.J. \& Cummins, J.T. (1985) GnRH pulse frequency determines LH pulse amplitude by altering the amount of releasable LH in the pituitary glands of ewes. J. Reprod. Fert. 73, 425-431.

Curlewis, J.D., Loudon, A.S.I. \& Coleman, A.P.M. (1988a) Oestrous cycles and the breeding season of the Père David's deer hind (Elaphurus davidianus). $J$. Reprod. Fert. 82, 119-126.

Curlewis, J.D., Loudon, A.S.I., Milne, J.A. \& McNeilly, A.S. (1988b) Effects of chronic long-acting bromocriptine treatment on liveweight, voluntary food intake, coat growth and breeding season in non-pregnant red deer hinds. J. Endocr. 119, 413-420.

I'Anson, H. \& Legan, S.J. (1988) Changes in LH pulse frequency and serum progesterone concentrations during the transition to breeding season in ewes. $J$. Reprod. Fert. 82, 341-351.

Karsch, F.J., Bittman, E.L., Foster, D.L., Goodman, R.L., Legan, S.J. \& Robinson, J.E. (1985) Neuroendocrine basis of seasonal reproduction. Recent Prog. Horm. Res. 40, 185-225.
Katongole, C.B., Naftolin, F. \& Short, R.V. (1971) Relationship between blood levels of luteinizing hormone and testosterone in bulls, and the effects of sexual stimulation. J. Endocr. 50, 457-466.

Land, R.B., Carr, W.R. \& Thompson, R. (1979) Genetic and environmental variation in the $L H$ response of ovariectomized sheep to LH-RH. J. Reprod. Fert. 56, $243-248$.

Land, R.B., Carr, W.R., McNeilly, A.S. \& Preece, R.D. (1980) Plasma FSH, LH, the positive feedback of oestrogen, ovulation and luteal function in the ewe given bromocriptine to suppress prolactin during seasonal anoestrus. J. Reprod. Fert. 59, 73-78.

Legan, S.J. \& Karsch, F.J. (1979) Neurodendocrine regulation of the estrous cycle and seasonal breeding in the ewe. Biol. Reprod. 20, 74-85.

Legan, S.J., Karsch, F.J. \& Foster, D.L. (1977) The endocrine control of seasonal reproductive function in the ewe: a marked change in response to the negative feedback action of estradiol on luteinizing hormone secretion. Endocrinology 101, 818-824.

Loudon, A.S.I., Milne, J.A., Curlewis, J.D. \& MeNeilly, A.S. (1989) A comparison of the seasonal hormone changes and patterns of growth, voluntary food intake and reproduction in juvenile and adult red deer (Cervus elaphus) and Père David's deer (Elaphurus davidianus) hinds. J. Endocr. 122, 733-745.

Loudon, A.S.I., McLeod, B.J. \& Curlewis, J.D. (1990) Pulsatile secretion of $\mathrm{LH}$ during the periovulatory and luteal phases of the oestrous cycle in the Père 
David's deer hind (Elaphurus davidianus). J. Reprod. Fert. 89, 663-670.

McLeod, B.J., Haresign, W. \& Lamming, G.E. (1982) The induction of ovulation and luteal function in seasonally anoestrous ewes treated with small-dose multiple injections of GnRH. J. Reprod. Fert. 65, 215-221.

McLeod, B.J., Brinklow, B.R., Curlewis, J.D. \& Loudon, A.S.I. (1991) Efficacy of intermittent or continuous administration of $\mathrm{GnRH}$ in inducing ovulation in early and late seasonal anoestrus in the Père David's deer hind (Elaphurus davidianus). J. Reprod. Fert. 91, 229-238.

McNatty, K.P., Gibb, M., Dobson, C. \& Thurley, D.C. (1981) Evidence that changes in luteinizing hormone secretion regulate the growth of the preovulatory follicle in the ewe. J. Endocr. 90, 375-389.

McNatty, K.P., Hudson, N.L., Henderson, K.M., Lun, S., Heath, D.A., Gibb, M., Ball, K., McDiarmid, J.M. \& Thurley, D.C. (1984) Changes in gonadotrophin secretion and ovarian antral follicular activity in seasonally breeding sheep throughout the year. $J$. Reprod. Fert. 70, 309-321.

McNeilly, A.S., O'Connell, M. \& Baird, D.T. (1982) Induction of ovulation and normal luteal function by pulsed injections of luteinizing hormone in anestrous ewes. Endocrinology 110, 1292-1299.

Niswender, G.D (1974) Influence of 2-Br- $\alpha$-ergocryptine on serum levels of prolactin and the estrous cycle in sheep. Endocrinology 94, 612-615.
Poulton, A.L., English, J., Symons, A.M. \& Arendt, J. (1987) Changes in plasma concentrations of LH, FSH and prolactin in ewes receiving melatonin and short-photoperiod treatments to induce early onset of breeding activity. Endocrinology 112, 103-111.

Reeves, J.J., Tarnavsky, G.K. \& Chakraborty, P.K. (1974) Serum LH in ewes treated with synthetic luteinizing hormone-releasing hormone/follicle stimulating hormone-releasing hormone (LH-RH/FSH-RH) at three periods of anestrus. J. Anim. Sci. 38, 369-373.

Rodway, R.G., Robinson, J.J. \& Phillippo, M. (1983) Ovulation rate in induced oestrous cycles of anoestrous ewes given bromocriptine. J. Reprod. Fert. 68, $265-267$.

Scaramuzzi, R.J. \& Baird, D.T. (1977) Pulsatile release of luteinizing hormone and the secretion of ovarian steroids in sheep during anestrus. Endocrinology 101, 1801-1806.

Walton, J.S., Evins, J.D., Fitzgerald, B.P. \& Cunningham, F.J. (1980) Abrupt decrease in daylength and shortterm changes in the plasma concentrations of FSH, LH and prolactin in anoestrous ewes. J. Reprod. Fert. 59, $163-171$.

Webster, G.M. \& Haresign, W. (1983) Seasonal changes in $\mathbf{L H}$ and prolactin concentrations in ewes of two breeds. J. Reprod. Fert. 67, 465-471.

Yuthasastrakosol, P., Palmer, W.M. \& Howland, B.E. (1977) Release of $\mathrm{LH}$ in anoestrous and cyclic ewes. J. Reprod. Fert. 50, 319-321.

Received 26 March 1990 